Article

\title{
Antagonistic Activity against Ascosphaera apis and Functional Properties of Lactobacillus kunkeei Strains
}

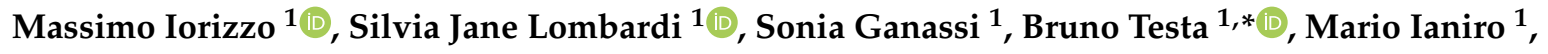 \\ Francesco Letizia ${ }^{1}$, Mariantonietta Succi ${ }^{1}$, Patrizio Tremonte ${ }^{1}$, Franca Vergalito ${ }^{1}$, \\ Autilia Cozzolino ${ }^{1}$, Elena Sorrentino ${ }^{1}{ }^{1}$, Raffaele Coppola ${ }^{1}{ }^{1}$, Sonia Petrarca ${ }^{2}$, \\ Massimo Mancini ${ }^{1}$ and Antonio De Cristofaro ${ }^{1}$ \\ 1 Department of Agriculture, Environmental and Food Sciences, University of Molise, \\ 86100 Campobasso, Italy; iorizzo@unimol.it (M.I.); silvia.lombardi@unimol.it (S.J.L.); \\ sonia.ganassi@unimol.it (S.G.); m.ianiro@studenti.unimol.it (M.I.); francesco.letizia@unimol.it (F.L.); \\ succi@unimol.it (M.S.); tremonte@unimol.it (P.T.); franca.vergalito@unimol.it (F.V.); \\ a.cozzolino@studenti.unimol.it (A.C.); sorrentino@unimol.it (E.S.); coppola@unimol.it (R.C.); \\ maxman@unimol.it (M.M.); decrist@unimol.it (A.D.C.) \\ 2 CONAPROA, Consorzio Nazionale Produttori Apistici, 86100 Campobasso, Italy; petrarca.s@conaproa.it \\ * Correspondence: bruno.testa@unimol.it
}

Received: 30 March 2020; Accepted: 17 May 2020; Published: 18 May 2020

check for updates

\begin{abstract}
Lactic acid bacteria (LAB) are an important group of honeybee gut microbiota. These bacteria are involved in food digestion, stimulate the immune system, and may antagonize undesirable microorganisms in the gastrointestinal tract. Lactobacillus kunkeei is a fructophilic lactic acid bacterium (FLAB) most frequently found in the gastrointestinal tracts of honeybees. Ascosphaera apis is an important pathogenic fungus of honeybee larvae; it can colonize the intestine, especially in conditions of nutritional or environmental stress that cause microbial dysbiosis. In this work, some functional properties of nine selected L. kunkeei strains were evaluated. The study focused on the antifungal activity of these strains against $A$. apis DSM 3116, using different matrices: cell lysate, broth culture, cell-free supernatant, and cell pellet. The cell lysate showed the highest antifungal activity. Moreover, the strains were shown to possess good cell-surface properties (hydrophobicity, auto-aggregation, and biofilm production) and a good resistance to high sugar concentrations. These L. kunkeei strains were demonstrated to be functional for use in "probiotic syrup", useful to restore the symbiotic communities of the intestine in case of dysbiosis and to exert a prophylactic action against $A$. apis.
\end{abstract}

Keywords: FLAB; chalkbrood disease; antifungal activity; Apis mellifera; probiotic syrup

\section{Introduction}

\subsection{Ascosphaera apis: The Causative Agent of Chalkbrood Disease}

The eusocial nature of Apis mellifera has always facilitated the maintenance of a relatively constant gut microbiota. This is due to interactions among individuals in the hive environment, and mainly to trophallaxis. This term refers to the direct transfer of food or fluids from one individual to another; it is especially common among social insects such as honeybees. Along with nutrients, trophallaxis also allows the horizontal transmission of gut bacteria [1,2]. The stomachs of honeybees are full of nutrients and are therefore a favorable environment for symbiotic microorganisms. These take part in various processes, including food digestion, detoxification of harmful molecules, supply of essential nutrients, participation in the host defense system, and protection from pathogens and parasites. The gut microbiota can be influenced by various factors that can cause dysbiosis, including temperature, nutritional deficiencies, pesticides, parasites, or pathogens [3-7]. Gut microflora alteration 
may have a strong negative impact on bee immune defense, metabolism, and cognitive mechanisms [4]. The honeybee intestine, which functions in digestion and food processing, is also the site of infections caused by pathogens such as A. apis, Nosema ceranae, Paenibacillus larvae, and probably by many of the honeybee viruses [4-7]. Chalkbrood is a fungal disease of the honeybee caused by the opportunistic pathogen A. apis, belonging to the heterothallic Ascomycota. This disease is now found throughout the world, and there are indications that the incidence of chalkbrood may be on the rise [8]. The severity of the disease depends on various factors such as environmental conditions, the genetic background and general health status of the honeybees, and the virulence level of the fungal strains [8-13]. Honeybee larvae are initially infected by ingesting food contaminated by sexual spores of $A$. apis. The ascospores germinate in the anaerobic environment of the alimentary canal, and the hyphae of the mycelium subsequently penetrate the intestinal walls of the larvae and deprive them of nutrients [8,9]. After a few days, the fungus becomes visible as a fluffy white growth covering the larvae. Chalkbrood can cause a reduction in honey production and a high percentage of larvae deaths, with significant economic consequences for beekeepers $[8,11,13]$. The initial phase of infection can be facilitated by any nutritional or environmental stress that causes microbial dysbiosis [4-6].

\subsection{Chalkbrood Disease Control by Symbiotic Bacteria}

The use of intestinal microbial symbionts, such as via dietary supplementation, can improve the health status of bees and increase their productivity, stimulating the immune defenses and exerting an antimicrobial action against unwanted and pathogenic microflora [14-20]. The presence of lactic acid bacteria (LAB) in the honeybee digestive system has been consistently reported in literature [21], and L. kunkeei is a bacterium frequently present in the intestinal microbiota of honeybees. It colonizes fructose-rich niches and is actually classified as fructophilic lactic acid bacterium (FLAB) [22-24]. L. kunkeei seems to protect its niche against bacterial competitors, although the mechanism of its antimicrobial activity is still in many respects unknown [25]. Some authors have assumed that the antimicrobial mechanisms of symbiotic bacteria evolved synergistically with bees, with the purpose of defending themselves and their hosts [2,6]. Inhibition could be based on a combination of active compounds such as proteins, peptides, fatty acids, organic acids, and hydrogen peroxide [26]. Furthermore, the ability of L. kunkeei to colonize the intestine and form a biofilm creates a barrier against unwanted microorganisms [26,27]. While there are many scientific data on the antimicrobial activity of L. kunkeei towards other microorganisms, and on that of other bacterial species against A. apis [28-34], reports of antifungal activity of L. kunkeei against A. apis are still few [35]. In recent years, a number of different strategies have been developed and implemented to control chalkbrood disease. A broad range of chemotherapeutic compounds have been tested for their ability to control A. apis [36,37]. Unfortunately, none of the compounds tested have been able to prevent the disease [38]. Furthermore, pesticide and antifungal chemical residues in honey represent a major human health hazard [39]. There is increased interest in investigations into new and effective chalkbrood control methods. The use of natural compounds for the disease control also represents an alternative. Some essential oils and other botanical extracts from plants, herbs, and spices exhibit antimicrobial activity against $A$. apis [40-45]. This antimicrobial activity is mainly due to the presence of phenolic and terpenoid compounds, which have well-known antimicrobial activity. However, the effect that these substances may have on bees' intestinal microflora and symbiotic LAB is not wholly known [46-52]. According to these considerations, the use of symbiotic FLAB in the prevention and biocontrol of honeybee pathogenic microorganisms, including chalkbrood disease, offers interesting possibilities [18]. The use of symbiotic bacteria, unlike synthetic or natural chemical compounds, does not adversely affect the balance of gut microbiota or impact honeybee health $[4,7,21,33]$. 
In this research, the antifungal activity of nine L. kunkeei strains against $A$. apis was evaluated. Moreover, further functional characteristics (auto-aggregation, biofilm production, hydrophobicity, and osmotic tolerance) were also assayed to assess suitability for use in a "probiotic syrup" to enhance the honeybee diet.

\section{Results}

\subsection{Screening of Bacteria for Antifungal Activity}

In the preliminary antifungal tests, all 85 L. kunkeei strains showed antifungal activity, but with different intensity: 8 strains had low intensity, 54 strains had medium intensity, and 23 strains had high intensity (Supplementary Materials Table S1).

Among the 23 strains that showed high antifungal activity, the strains K7, K18, K34, K40, K41, $\mathrm{K} 45, \mathrm{~K} 55$, K64, and $\mathrm{K} 112$ caused $100 \%$ inhibition and were selected for further biological control tests against $A$. apis DSM 3116 and subsequent analyses.

\subsection{Determination of Inhibitory Activity}

Figure 1 presents a heatmap of the inhibitory activity against $A$. apis DSM 3116 of the various matrices obtained from bacterial cell cultures. The broth cultures (BCs) of the nine selected strains confirmed total inhibition against the fungus, as already highlighted in the previous screening test.

In tests where the other matrices Cell Lysate (CL), Cell Pellet (CP) and Cell-Free Supernatant (CFS) were used, there was variability with often significant differences. Numeric data are shown in Supplementary Materials Table S2.

The CLs inhibited the fungus more than other matrices; in particular, the K7, K41, K45, and K55 L. kunkeei strains caused inhibition of more than $90 \%$. The CPs showed a high inhibitory activity ranging from $60 \%$ to $80 \%$, with the exception of the L. kunkeei K40 strain (19.8\%). The CFSs showed overall less inhibitory activity, between $8 \%$ and $24 \%$, with the exception of the CFS of L. kunkeei K7, which caused 53.8\% inhibition (Figure 2).

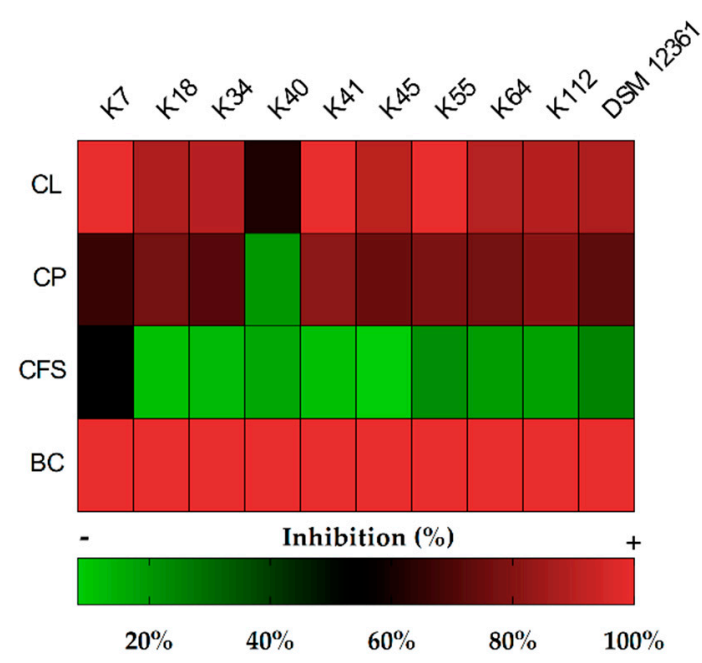

Figure 1. Heatmap of inhibition (\%) against Ascosphaera apis DSM 3116 (radial growth) on Malt Extract Agar (MEA) plates after 6 days, using culture broth (CB), cell pellets (CPs), cell-free supernatants (CFSs), and cell lysates (CLs) of the Lactobacillus kunkeei strains. 


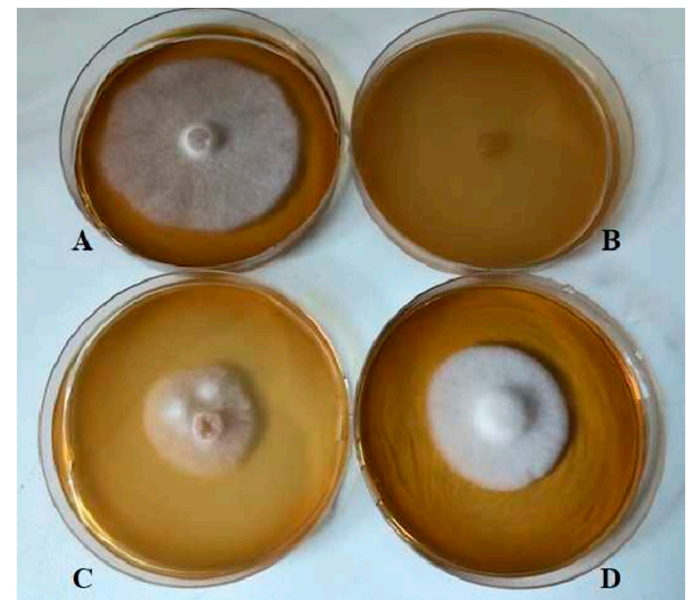

Figure 2. Inhibitory activity after 6 days on MEA agar plates of L. kunkeei $\mathrm{K} 7$ against A. apis DSM 3116. (A): A. apis; (B): A. apis + CL (cell lysate); (C): A. apis + CP (cell pellet); (D): A. apis + CFS (cell-free supernatant).

\subsection{Hydrophobicity and Auto-Aggregation}

This section reports the results of the tests of hydrocarbon adhesion and the auto-aggregation capacity of the selected L. kunkeei strains. The results are displayed graphically in Figure 3 and numerically in Supplementary Materials Table S3.

The hydrophobicity was highly variable depending on the strain and the hydrocarbon used, with significant differences in almost all cases. All the strains showed high adherence to toluene, while only three strains (K34, K41, and K55) showed high adherence to xylene. The adhesion to the two hydrocarbons gradually increased during the $60 \mathrm{~min}$ of tests, and the percentage of hydrophobicity obtained with toluene was significantly higher than that with xylene. In the test with toluene, three strains (K7, K34, and K41) showed an affinity greater than $90 \%$ after $60 \mathrm{~min}$; the other strains showed a high hydrophobicity between $80 \%$ and $90 \%$.

In the test with xylene, three strains (K34, K41, and K55) showed high hydrophobicity greater than $70 \%$; the K7, K18, K40, K45, K64, and DSM 12361 strains showed moderate hydrophobicity between $45 \%$ and $66 \%$; K112 alone showed a low affinity (31.91\%).

The results of the auto-aggregation test are shown in Table 1 . All nine strains demonstrated an ability of auto-aggregation that progressively and significantly increased over time.

The data showed significant differences among the various strains after 1, 2 and $5 \mathrm{~h}$. After $24 \mathrm{~h}$, there was less variability; in fact, the auto-aggregation capacity of the K7, K40, K64, K112, and DSM 12361 strains, ranging between $53.42 \%$ and $56.52 \%$, was not significantly different. 


\section{Hydrophobicity (\%)}

\section{A: $15 \min C T$}

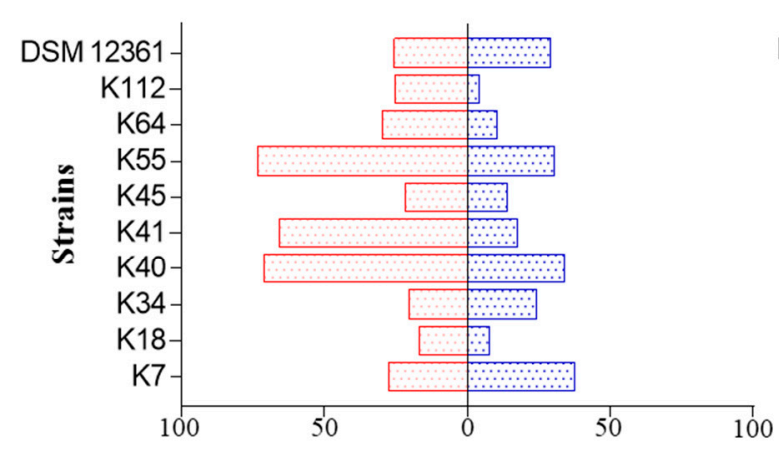

B: $30 \min$ CT

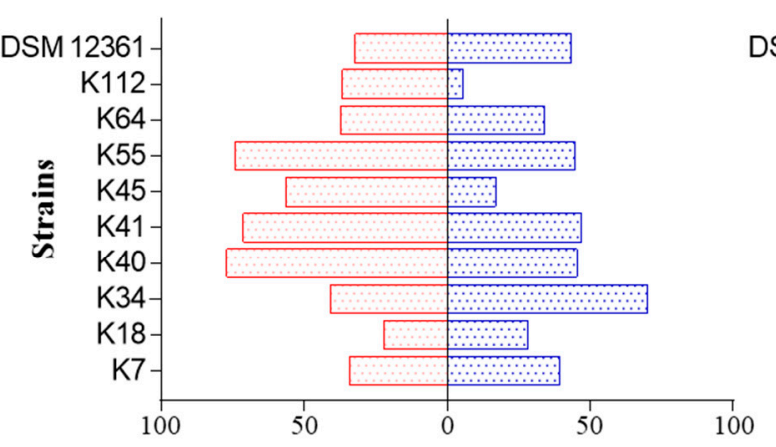

C: $60 \min C T$

C

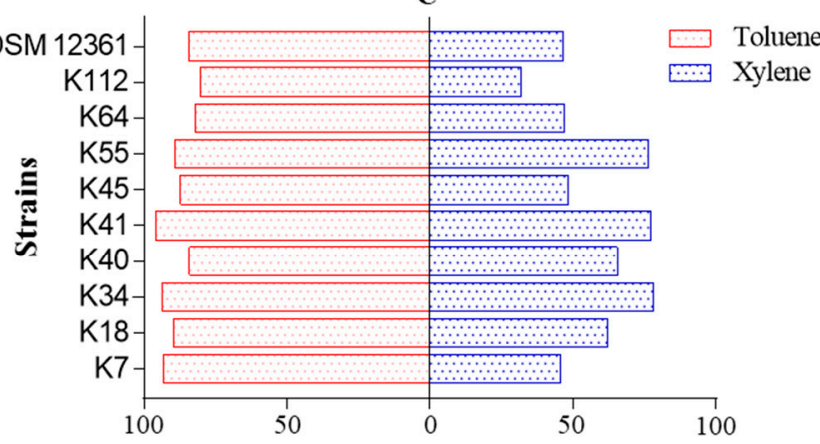

Figure 3. Adhesion of the L. kunkeei strains to toluene and xylene (expressed as hydrophobicity \%) measured using bacterial ability to adhere to hydrocarbons (BATH) test after different contact times (CTs). (A): $15 \mathrm{~min}$; (B): $30 \mathrm{~min}$; (C): $60 \mathrm{~min}$.

Table 1. Auto-aggregation (\%) of the L. kunkeei strains after 1, 2, 5, and $24 \mathrm{~h}$ of incubation at $37^{\circ} \mathrm{C}$. Results are shown as mean \pm standard deviation ( $\mathrm{n}=3$ ). Different lowercase letters (a-d) indicate significant differences by column, and different uppercase letters (A-I) in each row indicate significant differences by row $(p<0.05)$.

\begin{tabular}{|c|c|c|c|c|c|c|c|c|c|c|}
\hline \multirow{2}{*}{$\begin{array}{l}\text { Time } \\
\text { (Hours) }\end{array}$} & \multicolumn{10}{|c|}{ Auto-Aggregation (\%) } \\
\hline & K7 & K18 & K34 & K40 & K41 & K45 & K55 & K64 & K112 & DSM 12361 \\
\hline 1 & $11.10 \pm 0.88^{\mathrm{Ga}}$ & $4.49 \pm 0.14^{\mathrm{Ca}}$ & $4.51 \pm 0.10^{\mathrm{Ca}}$ & $15.41 \pm 0.54^{\mathrm{Ha}}$ & $3.25 \pm 0.12^{\mathrm{Ba}}$ & $0.76 \pm 0.02^{\mathrm{Aa}}$ & $5.55 \pm 0.22^{\mathrm{Da}}$ & $6.76 \pm 0.50^{\mathrm{Ea}}$ & $9.48 \pm 0.16^{\mathrm{Fa}}$ & $9.32 \pm 0.20^{\mathrm{Fa}}$ \\
\hline 2 & $18.40 \pm 1.18^{\mathrm{Fb}}$ & $8.62 \pm 0.36^{\mathrm{Cb}}$ & $10.94 \pm 0.89^{\mathrm{Db}}$ & $17.40 \pm 1.08^{\mathrm{Fb}}$ & $7.56 \pm 0.32^{\mathrm{Bb}}$ & $2.11 \pm 0.10^{\mathrm{Ab}}$ & $10.43 \pm 0.27^{\mathrm{Db}}$ & $10.61 \pm 0.35^{\mathrm{Db}}$ & $16.10 \pm 0.96^{\mathrm{Fb}}$ & $13.66 \pm 0.35^{\mathrm{Eb}}$ \\
\hline 5 & $22.71 \pm 1.00^{\mathrm{Fc}}$ & $12.41 \pm 0.16^{\mathrm{Cc}}$ & $11.31 \pm 0.34^{\mathrm{Bb}}$ & $24.94 \pm 0.04^{\mathrm{Hc}}$ & $25.20 \pm 0.19^{\mathrm{Ic}}$ & $6.23 \pm 0.59^{\mathrm{Ac}}$ & $14.82 \pm 0.98^{\mathrm{Dc}}$ & $15.27 \pm 0.12^{\mathrm{Dc}}$ & $23.42 \pm 0.31^{\mathrm{Gc}}$ & $19.70 \pm 0.65^{\mathrm{Ec}}$ \\
\hline 24 & $53.42 \pm 1.21^{\mathrm{Bd}}$ & $62.23 \pm 1.32^{\mathrm{Dd}}$ & $65.62 \pm 1.37^{\mathrm{Ec}}$ & $56.52 \pm 1.95^{\mathrm{Cd}}$ & $68.10 \pm 1.71^{\mathrm{Fd}}$ & $41.81 \pm 0.42^{\mathrm{Ad}}$ & $62.30 \pm 0.99^{\mathrm{Dd}}$ & $56.12 \pm 2.39^{\mathrm{Cd}}$ & $55.80 \pm 0.94^{\mathrm{Cd}}$ & $55.42 \pm 3.21^{\mathrm{Cd}}$ \\
\hline
\end{tabular}




\subsection{Biofilm Production}

Figure 4 shows the heatmap of biofilm production in MRS broth without sugar or supplemented with $1 \%$ glucose, $1 \%$ fructose, or $1 \%$ sucrose. The amount of biofilm was assessed by measuring the optical density (OD), and numerical data are provided in Supplementary Materials Table S4. All the L. kunkeei strains tested were able to produce biofilms, but in different amounts depending on the presence and type of added sugar.

With the addition of $1 \%$ of glucose or $1 \%$ fructose, the biofilm production for each bacterial strain was similar, but among the various strains, the OD values were significantly different.

In MRS without sugar, five strains (K34, K41, K55, K64, and DSM 12361) produced the largest amounts of biofilm, to a significantly different degree than the other strains. With the addition of sucrose, the largest amounts of biofilms were produced by K7, K18, K34, K40, K41, K45, and K55 L. kunkeei strains, with the differences among them not statistically significant.

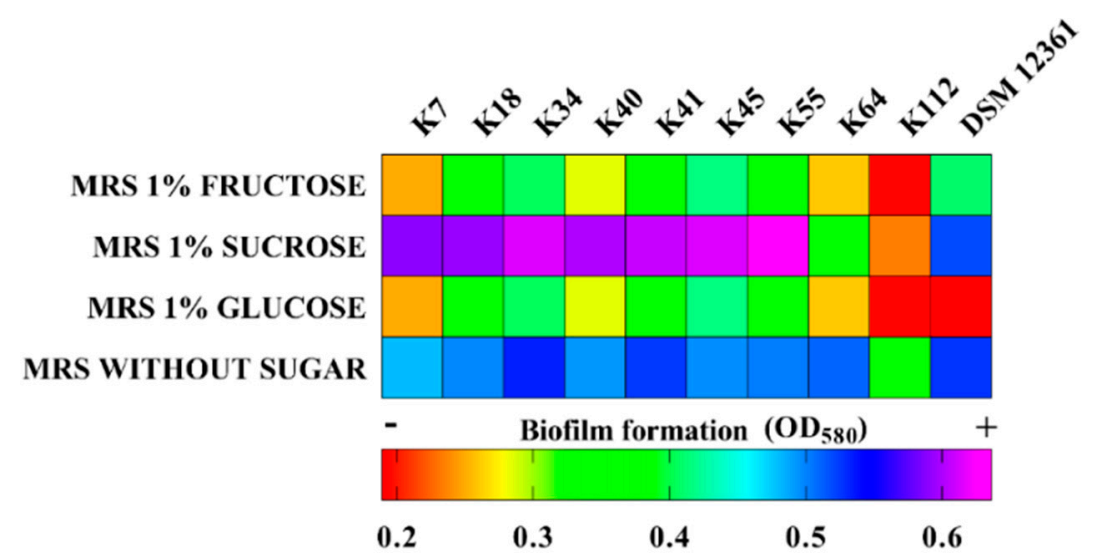

Figure 4. Biofilm formation in vitro of the L. kunkeei strains, expressed as Optical Density (OD) value at $580 \mathrm{~nm}$.

\subsection{Bacterial Survival in Sugar Syrup}

The results of strains' survival in sugar syrup are shown in Table 2. In Test A ( $40 \%$ glucose $+20 \%$ fructose, $\mathrm{pH} 4.2)$, after $24 \mathrm{~h}$ of incubation, all the strains maintained a high viable cell density between 6.90 and $8.10 \log \mathrm{CFU} / \mathrm{mL}$; after $48 \mathrm{~h}$, although with significant differences, the all strains maintained a good cell density ranging between 4.80 and $7.51 \log \mathrm{CFU} / \mathrm{mL}$.

In Test B ( $40 \%$ glucose $+30 \%$ fructose at $\mathrm{pH} 4.2)$, after $24 \mathrm{~h}$, the bacteria, except the strains DSM 12361 and K112, showed concentrations of viable cells greater than $6.0 \log$ CFU $/ \mathrm{mL} ;$ after $48 \mathrm{~h}$, only K18 and $\mathrm{K} 55$ maintained a good viable cell density $(>5.0 \log \mathrm{CFU} / \mathrm{mL})$, with results significantly different from the other strains. The lowest concentration was that of the DSM 12361 strain $(2.91 \log \mathrm{CFU} / \mathrm{mL})$. In Test C (50\% of sucrose at $\mathrm{pH} 4.2)$, after $24 \mathrm{~h}$, the concentration of viable cells for all strains was between 7.10 and $8.50 \log \mathrm{CFU} / \mathrm{mL}$, while after $48 \mathrm{~h}$, although with significant differences, all strains maintained a good viable cell density between 5.94 and $7.94 \log \mathrm{CFU} / \mathrm{mL}$. 
Table 2. Survival of the L. kunkeei strains in different sugar syrups after 24 and $48 \mathrm{~h}$ of incubation at $20^{\circ} \mathrm{C}$. Results are shown as mean \pm standard deviation ( $\mathrm{n}=3$ ). For every sugar syrup, different lowercase letters (a-c) indicate significant differences in columns, and different uppercase letters (A-I) indicate significant differences in rows $(p<0.05)$.

\begin{tabular}{|c|c|c|c|c|c|c|c|c|c|c|c|}
\hline \multirow{2}{*}{$\begin{array}{l}\text { Time } \\
\text { (Hours) }\end{array}$} & \multirow{2}{*}{$\begin{array}{l}\text { Sugar Syrup } \\
\text { Composition }\end{array}$} & \multicolumn{10}{|c|}{ Survival $(\log \mathrm{CFU} / \mathrm{mL})$ of L. kunkeei Strains } \\
\hline & & K7 & K18 & K34 & K40 & K41 & K45 & K55 & K64 & K112 & DSM 12361 \\
\hline $\mathrm{T}_{0}$ & \multirow{3}{*}{$\begin{array}{l}40 \% \text { glucose } \\
20 \% \text { fructose }\end{array}$} & $8.41 \pm 0.02^{\mathrm{Bc}}$ & $8.38 \pm 0.04^{\mathrm{Bc}}$ & $8.44 \pm 0.06^{\mathrm{Bc}}$ & $8.23 \pm 0.03^{\mathrm{Ac}}$ & $8.19 \pm 0.04^{\mathrm{Ac}}$ & $8.17 \pm 0.02^{\mathrm{Ac}}$ & $8.26 \pm 0.05^{\mathrm{Ac}}$ & $8.24 \pm 0.01^{\mathrm{Ac}}$ & $8.36 \pm 0.02^{\mathrm{Bc}}$ & $8.40 \pm 0.04^{\mathrm{Bc}}$ \\
\hline $\mathrm{T}_{24}$ & & $7.89 \pm 0.01 \mathrm{~Eb}$ & $8.10 \pm 0.01^{\mathrm{Gb}}$ & $7.60 \pm 0.07^{\mathrm{Cb}}$ & $7.12 \pm 0.05^{\mathrm{Bb}}$ & $7.20 \pm 0.04^{\mathrm{Bb}}$ & $7.80 \pm 0.06^{\mathrm{Db}}$ & $7.18 \pm 0.08^{\mathrm{Bb}}$ & $6.90 \pm 0.04^{\mathrm{Ab}}$ & $8.01 \pm 0.01^{\mathrm{Fb}}$ & $6.90 \pm 0.02^{\mathrm{Ab}}$ \\
\hline $\mathrm{T}_{48}$ & & $6.62 \pm 0.03^{\mathrm{Fa}}$ & $7.51 \pm 0.02^{\mathrm{Ha}}$ & $4.90 \pm 0.02^{\mathrm{Ba}}$ & $5.84 \pm 0.05^{\mathrm{Ca}}$ & $6.29 \pm 0.01^{\mathrm{Da}}$ & $6.47 \pm 0.02^{\mathrm{Ea}}$ & $5.84 \pm 0.01 \mathrm{Ca}$ & $5.90 \pm 0.02^{\mathrm{Ca}}$ & $6.84 \pm 0.03^{\mathrm{Ga}}$ & $4.80 \pm 0.04^{\mathrm{Aa}}$ \\
\hline $\mathrm{T}_{0}$ & \multirow{3}{*}{$\begin{array}{l}40 \% \text { glucose } \\
30 \% \text { fructose }\end{array}$} & $8.66 \pm 0.044^{\mathrm{Ec}}$ & $8.50 \pm 0.03^{\mathrm{Dc}}$ & $8.43 \pm 0.05^{\mathrm{Dc}}$ & $8.06 \pm 0.08^{\mathrm{Ac}}$ & $8.46 \pm 0.08^{\mathrm{Dc}}$ & $8.43 \pm 0.02^{\mathrm{Dc}}$ & $8.25 \pm 0.04^{\mathrm{Bc}}$ & $8.23 \pm 0.05^{\mathrm{Bc}}$ & $8.30 \pm 0.02^{\mathrm{Cc}}$ & $8.45 \pm 0.06^{\mathrm{Dc}}$ \\
\hline $\mathrm{T}_{24}$ & & $6.23 \pm 0.02^{\mathrm{Db}}$ & $7.12 \pm 0.05^{\mathrm{Gb}}$ & $6.24 \pm 0.04^{\mathrm{Db}}$ & $6.90 \pm 0.02^{\mathrm{Fb}}$ & $6.84 \pm 0.01^{\mathrm{Eb}}$ & $6.11 \pm 0.05^{\mathrm{Cb}}$ & $6.12 \pm 0.02^{\mathrm{Cb}}$ & $6.24 \pm 0.06^{\mathrm{Db}}$ & $5.97 \pm 0.02^{\mathrm{Bb}}$ & $4.97 \pm 0.07^{\mathrm{Ab}}$ \\
\hline $\mathrm{T}_{48}$ & & $4.54 \pm 0.04^{\mathrm{Da}}$ & $5.75 \pm 0.05^{\mathrm{Ha}}$ & $4.61 \pm 0.01^{\mathrm{Ea}}$ & $4.01 \pm 0.02^{\mathrm{Ba}}$ & $4.98 \pm 0.03^{\mathrm{Ga}}$ & $4.73 \pm 0.03^{\mathrm{Fa}}$ & $5.59 \pm 0.01^{\mathrm{Ia}}$ & $4.94 \pm 0.04^{\mathrm{Ga}}$ & $4.20 \pm 0.02^{\mathrm{Ca}}$ & $2.91 \pm 0.01^{\mathrm{Aa}}$ \\
\hline $\mathrm{T}_{0}$ & \multirow{3}{*}{$50 \%$ sucrose } & $8.20 \pm 0.04^{\mathrm{Bc}}$ & $8.10 \pm 0.01^{\mathrm{Ac}}$ & $8.50 \pm 0.03^{\mathrm{Fc}}$ & $8.40 \pm 0.06^{\mathrm{Dc}}$ & $8.49 \pm 0.07^{\mathrm{Ec}}$ & $8.23 \pm 0.01^{\mathrm{Bc}}$ & $8.10 \pm 0.04^{\mathrm{Ac}}$ & $8.53 \pm 0.07^{\mathrm{Fc}}$ & $8.50 \pm 0.06^{\mathrm{Fc}}$ & $8.30 \pm 0.04^{\mathrm{Cc}}$ \\
\hline $\mathrm{T}_{24}$ & & $7.20 \pm 0.04^{\mathrm{Bb}}$ & $8.20 \pm 0.03^{\mathrm{Gb}}$ & $7.90 \pm 0.02^{\mathrm{Fb}}$ & $7.79 \pm 0.06^{\mathrm{Eb}}$ & $8.50 \pm 0.01^{\mathrm{Hb}}$ & $7.60 \pm 0.02^{\mathrm{Db}}$ & $7.10 \pm 0.01^{\mathrm{Ab}}$ & $7.60 \pm 0.05^{\mathrm{Db}}$ & $7.50 \pm 0.07^{\mathrm{Cb}}$ & $7.20 \pm 0.06^{\mathrm{Bb}}$ \\
\hline $\mathrm{T}_{48}$ & & $7.00 \pm 0.05^{\mathrm{Da}}$ & $7.94 \pm 0.01^{\mathrm{Fa}}$ & $5.94 \pm 0.02^{\mathrm{Aa}}$ & $6.85 \pm 0.01^{\mathrm{Ca}}$ & $7.30 \pm 0.05^{\mathrm{Ea}}$ & $6.89 \pm 0.02^{\mathrm{Ca}}$ & $6.85 \pm 0.01^{\mathrm{Ca}}$ & $6.90 \pm 0.05^{\mathrm{Ca}}$ & $6.90 \pm 0.06^{\mathrm{Ca}}$ & $6.50 \pm 0.06^{\mathrm{Ba}}$ \\
\hline
\end{tabular}




\section{Discussion}

\subsection{Antifungal Activity}

In the inhibition test against A. apis, all nine L. kunkeei strains showed strong antifungal activity. Complete inhibition occurred with the use of BC, which was most likely due to the interaction of several factors. The inhibitory effects observed when using CP and CL were stronger than those obtained with the CFS. Our results suggest that the antimicrobial action of LAB is often due to a complex interaction among different compounds (e.g., organic acids, fatty acids, proteinaceous compounds, phenolic acids, hydrogen peroxide, reuterin) contained in the different matrices used, as highlighted in other research [53-56]. The action in CP could be based on either nutritional competition or compounds linked to their walls. The major inhibitory effect after cell lysis is probably due to the release of further antimicrobial compounds from the cell wall or from the cytoplasm. In general, LAB can produce extracellular proteins such as bacteriocins, molecular chaperones, enzymes, and lipoproteins [57]. Glycolytic and ribosomal proteins generally contained in the cytoplasm can be found on the bacterial cell surface. It is hypothesized that these proteins, once they are localized on the surface, could develop different functions such as biofilm production and antimicrobial activity [21,58,59]. The L. kunkeei strains tested in our experiments were shown to possess substances biologically active against $A$. apis. Our results confirmed a potentially antagonist role of L. kunkeei against pathogenic microorganisms that use the digestive channels of bees as a site of infection [22,60,61].

\subsection{Cell-Surface Properties}

The ability of probiotic bacteria to adhere to intestinal epithelial cells involves various surface properties, including hydrophobicity and auto-aggregation. These characteristics are an important prerequisite for colonization of the host intestinal tract [62-67]. The probiotic bacteria are linked to the receptors of intestinal mucosa, thus preventing the adherence of pathogenic microorganisms which are subsequently eliminated from the intestine $[62,63]$. The quality of adherence, usually strain-specific, can also cause increased persistence in the gastrointestinal tract. The adherence property is most likely due to complex interactions between positive and negative charges between hydrophobic and hydrophilic components of the bacterial surface [64]. As reported in previous studies, hydrophobicity, together with auto-aggregation, is considered an important bacterial surface feature $[65,66]$, and correlations between them may be observed [67]. In our study, the hydrophobicity was evaluated by BATH method using two different hydrocarbons, xylene and toluene [67], and classified into three groups: low $(0 \%$ to $35 \%)$, moderate (36\% to $70 \%$ ), and high hydrophobicity (71\% to $100 \%$ ) [68]. The BATH assay showed significant variations depending on the hydrocarbon used. The nine L. kunkeei strains all showed an enhanced adherence capacity to toluene than xylene. In previous studies, it has been reported that the viscosity of the hydrocarbon or the size of droplets formed during mixing may determine this difference [69].

In the future, it will be necessary to perform this assay with cell lines to confirm the adhesion of the tested strains to epithelial cells.

Auto-aggregation is a characteristic that promotes the stability of microbial strains in the gastrointestinal tract (GIT). This phenotypic characteristic, as several studies have shown, can be constitutive or induced by nutritional and environmental stress conditions ( $\mathrm{pH}$, temperature, presence of competing microorganisms, etc.) [63-70]. Our results showed that the nine L. kunkeei strains had high values of auto-aggregation, in line with previous research [71]. The bacterial auto-aggregation capacity is related to the building of a biofilm. Some microorganisms have the ability to form biofilms to adhere to surfaces. Bacterial biofilm production is a highly complex process depending on the expression of specific genes, and this process is a means by which to adapt to new nutritional and environmental conditions [70]. Several studies have reported that in this phase of adaptation, bacteria produce extracellular polymeric substances (EPS), especially exopolysaccharides and proteinaceous compounds, that may be constituents of the biofilm and could exert an antimicrobial action [72-76]. 
In our study, all the L. kunkeei strains were shown to be able to produce biofilm, with different intensities.

In this regard, the best results were obtained with the use of $1 \%$ sucrose and without adding sugar. According to some authors, it would seem that in the presence of a nutritional stress, the strains used the biofilm as a defense mechanism [21,77-79]. Thanks to its ability to produce biofilms, L. kunkeei persists in the intestine where there is an extensive flow of sugars, enzymes, and water, and the constant invasion of foreign microbes following the ingestion of flower nectar during foraging. As highlighted in other research, the biofilms formed by some L. kunkeei strains favor their persistence in the bee intestine and increase their inhibition power against undesirable microorganisms $[15,18,20,79]$.

\subsection{Survival in Sugar Syrups}

In our experimental studies, we evaluated the capacity of L. kunkeei strains to tolerate a high concentration of sugars to verify their functionality as probiotics in a sugar syrup used as additional nutrition for bees. The results proved that all nine strains, in all combinations, had a good osmotic tolerance, in agreement with a previous study [22]. This feature would ensure a high bacterial vitality if $L$. kunkeei were added to sugar syrups used as additional food in hives. Moreover, honeybees are attracted by highly concentrated sugar syrup; this behavior becomes important when finding a compromise between maximum attractiveness for bees and survival of lactic bacteria.

\subsection{Perspectives}

Several studies have shown that the use of probiotic bacteria in honeybee diet may have several positive effects, including increasing the immune defenses of bees, strengthening or rebalancing the intestinal microflora in case of dysbiosis, improving bee productivity, and strengthening defense systems against pathogenic microorganisms [3,23,30-35,80-85].

The novelty of our work was to select nine symbiotic $L$. kunkeei strains for use in a honeybee diet for prophylactic and therapeutic purposes against A. apis. The selected L. kunkeei strains showed functional properties (cell surface properties, antifungal activity, and osmotic tolerance) for use as probiotics in sugar syrups to be used in the supplemental feeding of honeybees.

\section{Materials and Methods}

\subsection{Microbial Cultures}

For this study, 85 selected L. kunkeei strains were used, isolated from bee bread, honey stomach, and honeybee guts of Apis mellifera L. (Supplementary Materials Table S1). These bacteria belong to the Di.A.A.A (Department of Agricultural, Environmental and Food Sciences) collection of University of Molise [85].

A. apis DSM 3116 and L. kunkeei DSM 12361, belonging to the DSMZ collection (German Collection of Microorganism and Cell Cultures $\mathrm{GmbH}$ ), were used as reference cultures. We used the DSM 12361 strain as a reference because it has demonstrated a capacity in previous research to produce EPS [76-78].

\subsection{Screening of Bacteria for Antifungal Activity}

The antifungal activity screening for the 85 L. kunkeei strains was performed using the overlay method as described by Magnusson et al. [86], with some modification. The strains were cultivated in MRS broth (Oxoid Ltd., Hampshire, UK) at $37^{\circ} \mathrm{C}$ for $12 \mathrm{~h}$, after which $10 \mu \mathrm{L}$ of the bacterial culture $\left(10^{8} \mathrm{CFU} / \mathrm{mL}\right)$ was spotted onto the surface of MRS agar plates and plates were incubated at $37^{\circ} \mathrm{C}$ for $24 \mathrm{~h}$. Fungal culture of A. apis DSM 3116 was obtained by growing on a MEA plate (Oxoid Ltd., Hampshire, UK) aerobically at $37^{\circ} \mathrm{C}$ for 5 days. After that, a mycelium disc of $6 \mathrm{~mm}$ diameter was taken, dissolved in physiological solution $(0.9 \% \mathrm{NaCl})$, and vortexed for $5 \mathrm{~min}$; subsequently, $1 \mathrm{~mL}$ of the fungal suspension was inoculated into a tube containing $9 \mathrm{~mL}$ of MEA soft agar $(0.05 \%$ malt 
extract and $0.7 \%$ agar) that was overlaid in the Petri dishes with the various bacterial strains. A plate containing MEA with fungal suspension and without bacteria was used as a control. After $72 \mathrm{~h}$ of incubation at $37^{\circ} \mathrm{C}$, the inhibition activity was measured as the diameter $(\mathrm{mm})$ of the clear zone around the bacterial spot; the different activity levels of the bacteria were classified as follows: $0-30 \mathrm{~mm}$ : low activity; 30-60 mm: medium activity; $>60 \mathrm{~mm}$ : high activity.

\subsection{Determination of Inhibitory Activity}

The inhibitory activity was performed using the following matrices: BC, CP, CFS, and CL. In order to obtain the fractions, every single strain was cultivated in MRS broth and incubated at $37^{\circ} \mathrm{C}$ for $12 \mathrm{~h}$, reaching a cell concentration of $10^{8} \mathrm{CFU} / \mathrm{mL}$. This culture without any further treatment was the $\mathrm{BC}$ matrix. Five milliliters of the bacterial culture were centrifuged at $8000 \mathrm{rpm}$ for $15 \mathrm{~min}$ at $4{ }^{\circ} \mathrm{C}$. After centrifugation, the supernatant was sterilized by filtration $(0.22 \mu \mathrm{m}$ pore size cellulose acetate filter), and this fraction represented the CFS. The remaining pellet was washed and resuspended in $5 \mathrm{~mL}$ of physiological solution, which was the CP fraction. In order to obtain the CL fraction, $5 \mathrm{~mL}$ of the $\mathrm{BC}$ was centrifuged and the pellet washed, resuspended in $5 \mathrm{~mL}$ of physiological solution, and sonicated $\left(20 \mathrm{kHz}\right.$ for $30 \mathrm{~min}$ a $\left.45^{\circ} \mathrm{C}\right)$ to promote cellular lysis. A volume of $5 \mathrm{~mL}$ of each matrix (BC, CP, CFS, and CL), was added to $15 \mathrm{~mL}$ of MEA; the preparation was poured into $90 \mathrm{~mm}$ Petri dishes. After solidification, a mycelium disc ( $6 \mathrm{~mm}$ diameter) of $A$. apis (DSM 3116) was placed in the middle of each Petri dish and incubated at $37^{\circ} \mathrm{C}$ in aerobic conditions. The antifungal activity was evaluated by measuring the hyphal radial growth ( $\mathrm{cm}$ diameter) after 6 days of incubation and expressed as percentage of inhibition using the following formula: \% $I=[1-(\mathrm{Ds} / \mathrm{Dc})] \times 100$, where Ds was the hyphal diameter of the sample and Dc was the hyphal diameter of the control (MEA only with fungus).

\subsection{Hydrophobicity Assay}

The determination of cell-surface hydrophobicity was evaluated on L. kunkeei strains basing on the bacterial ability to adhere to hydrocarbons (BATH), according to the procedure described by Cozzolino et al. [87], using xylene and toluene as solvents. The bacteria were grown overnight at $37^{\circ} \mathrm{C}$ in MRS broth. Cultures were collected by centrifugation $\left(8000 \mathrm{rpm}\right.$ for $10 \mathrm{~min}$ at $4{ }^{\circ} \mathrm{C}$ ) during the logarithmic growth phase, washed twice and resuspended in physiological solution to an optical density of approx. $0.5\left(\mathrm{~A}_{580}\right)$, in order to standardize the bacterial concentration at $10^{8} \mathrm{CFU} / \mathrm{mL}$. An equal volume of hydrocarbon (xylene or toluene) was then added to the bacterial suspension, mixed (in a vortex-type mixer) for $5 \mathrm{~min}$ and incubated at $37^{\circ} \mathrm{C}$. The aqueous phase was carefully removed after 15,30 , and $60 \mathrm{~min}$ of incubation at room temperature and the absorbance was measured at $580 \mathrm{~nm}$ using a spectrophotometer (PerkinElmer 1420 Multilabel Counter). Hydrophobicity was calculated as the percentage decrease in $\mathrm{OD}$ of the initial bacterial suspension and was expressed using the following formula: \% Hydrophobicity $=\left(\mathrm{OD}_{0}-\mathrm{ODt} / \mathrm{OD}_{0}\right) \times 100$, where ODt represents the absorbance value after extraction with hydrocarbons $(15,30$, and $60 \mathrm{~min})$ and $\mathrm{OD}_{0}$ represents the absorbance value before extraction with hydrocarbons. The L. kunkeei strains were classified into three roups on the basis of their affinity to hydrocarbons: low ( $0 \%$ to $35 \%)$, moderate (36\% to $70 \%)$, and high hydrophobicity (71\% to $100 \%)$ [68].

\subsection{Auto-Aggregation}

The auto-aggregation assay was performed according to Collado et al. [67]. The bacterial suspensions were prepared as described for BATH test. Auto-aggregation was measured at 1, 2, 5, and $24 \mathrm{~h}$ of incubation at $37^{\circ} \mathrm{C}$, after which the OD at 580nm of the upper suspension was measured using a spectrophotometer (PerkinElmer 1420 Multilabel Counter). The percentage of auto-aggregation was calculated using the following formula: Auto-aggregation $\%(\mathrm{~A})=\left(1-\mathrm{ODt} / \mathrm{OD}_{0}\right) \times 100$ where $\mathrm{OD}_{0}$ is the absorbance at time 0 and ODt is the absorbance detected after 1, 2, 5, and $24 \mathrm{~h}$ [64]. 


\subsection{Biofilm Production}

Biofilm production was evaluated as described by Cozzolino et al. [87] with some modifications. L. kunkeei strains were grown overnight at $37^{\circ} \mathrm{C}$ in MRS broth. The bacterial cells were harvested by centrifugation at $8000 \mathrm{rpm}$ for $10 \mathrm{~min}$ at $4{ }^{\circ} \mathrm{C}$, washed twice with PBS (Sigma-Aldrich), and resuspended in MRS broth without glucose (Liofilchem, Italy) and in MRS broth supplemented with $1 \%$ glucose, $1 \%$ fructose, or $1 \%$ sucrose. Three aliquots of $200 \mu \mathrm{L}$ of each bacterial suspension were added to a 96 well polystyrene microtiter plate. Negative controls were constituted by wells filled with uninoculated culture media. Microtiter plates were incubated for $24 \mathrm{~h}$ at $37^{\circ} \mathrm{C}$. The medium was removed from each well and plates were washed three times with a sterile physiological solution to remove unattached cells. The remaining attached cells were fixed with $200 \mu \mathrm{L}$ of $99 \%$ methanol (Sigma-Aldrich) per well. After $15 \mathrm{~min}$, wells were emptied and left to dry. Wells were then stained for $5 \mathrm{~min}$ with $200 \mu \mathrm{L}$ of $2 \%$ crystal violet (Liofilchem, Italy) per well. The excess stain was removed by washing three times with a sterile saline solution. After the plates were air-dried, the adherent cells were resuspended in $160 \mu \mathrm{L}$ of $33 \%(v / v)$ glacial acetic acid (Sigma-Aldrich). The absorbance values at $580 \mathrm{~nm}$, measured using an automated Multilabel Counter (PerkinElmer 1420), represent the biofilm formation capacity.

\subsection{Bacterial Survival in Sugar Syrup}

The L. kunkeei strains were grown overnight in MRS broth at $37^{\circ} \mathrm{C}$. After that, cells were harvested by centrifugation at $8000 \mathrm{rpm}$ for $10 \mathrm{~min}$ at $4{ }^{\circ} \mathrm{C}$. The fresh pellets were washed twice with physiological solution and inoculated into the sugar syrup in order to measure an initial concentration of $10^{8} \mathrm{CFU} / \mathrm{mL}$. The experimental conditions were as follows: Test A: sugar syrup constituted of $40 \%$ glucose $+20 \%$ fructose in distilled water at $\mathrm{pH} 4.2$; Test B: sugar syrup constituted of $40 \%$ glucose $+30 \%$ fructose in distilled water at $\mathrm{pH} 4.2$; Test $\mathrm{C}$ : sugar syrup constituted of $50 \%$ sucrose in distilled water at $\mathrm{pH}$ 4.2. The sugar syrup was acidified using $\mathrm{HCl} 1 \mathrm{~N}$ and sterilized by filtration $(0.22 \mu \mathrm{m}$ pore size cellulose acetate filter). The experiments were performed at $20^{\circ} \mathrm{C}$. The cell viability of the bacteria was determined at 0,24 , and $48 \mathrm{~h}$ by plating on MRS agar $\left(37^{\circ} \mathrm{C}\right.$ for $72 \mathrm{~h}$ in anaerobic conditions).

\subsection{Statistical Analysis}

All data are expressed as mean \pm standard deviation (S.D.) of three independent experiments. Statistical analysis was performed via an analysis of variance (ANOVA) followed by the Tukey's multiple comparison. Statistical significance was attributed to $p$-values $<0.05$. The software SPSS (IBM SPSS Statistics 21) was used for the analysis.

\section{Conclusions}

The results showed the capacity of selected L. kunkeei strains to inhibit A. apis and highlighted their important properties, such as ability to form biofilms, high auto-aggregation, and hydrophobicity, all prerequisites for candidacy as probiotic microorganisms in a honeybee diet. In addition, the selected L. kunkeei strains showed high osmotic tolerance, a functional requirement for the probiotication of sugar syrups to restore or strengthen the symbiotic communities in honeybee guts in case of microbial dysbiosis.

Future research will be conducted in vivo/in situ on the antimicrobic activity of these bacteria and the effects on honeybee health and productivity.

Supplementary Materials: The following are available online at http://www.mdpi.com/2079-6382/9/5/262/s1. Table S1: L. kunkeei strains collection; Table S2: Inhibition; Table S3: Hydrophobicity; Table S4: Biofilm production.

Author Contributions: Conceptualization, M.I. (Massimo Iorizzo) and R.C.; Data curation, M.S., P.T. and E.S.; Formal analysis, B.T., S.J.L., S.G., S.P., F.V. and A.C.; Funding acquisition, M.M. and A.D.C.; Investigation, B.T., S.P. and P.T.; Methodology, S.J.L., S.G., B.T., F.V. and A.C.; Project administration, S.P. and M.M.; Resources, R.C. and A.D.C.; Software, F.L. and M.M.; Supervision, R.C. and A.D.C.; Validation, M.S.; Writing-original draft, M.I. (Massimo Iorizzo) and B.T.; Writing-review \& editing, M.I. (Mario Ianiro), S.G. and F.L. All authors have read and agreed to the published version of the manuscript. 
Funding: This research was carried out as part of the project "BEEOBSERVER" financed by Department of Agriculture, Environmental and Food Sciences, University of Molise, CB, Italy. ID: H32F16000610005.

Conflicts of Interest: The authors declare that they have no conflicts of interest.

\section{References}

1. Kwong, W.; Moran, N.A. Gut microbial communities of social bees. Nat. Rev. Microbiol. 2016, 14, $374-384$. [CrossRef] [PubMed]

2. Powell, J.E.; Martinson, V.G.; Urban-Mead, K.; Moran, N.A. Routes of acquisition of the gut microbiota of Apis mellifera. Appl. Environ. Microbiol. 2014, 80, 7378-7387. [CrossRef] [PubMed]

3. Cox-Foster, D.L.; Conlan, S.; Holmes, E.C.; Palacios, G.; Evans, J.D.; Moran, N.A.; Quan, P.L.; Briese, T.; Hornig, M.; Geiser, D.M.; et al. A metagenomic survey of microbes in honey bee colony collapse disorder. Science 2007, 318, 283-287. [CrossRef]

4. Hamdi, C.; Balloi, A.; Essanaa, J.; Gonella, E.; Raddadi, N.; Ricci, I.; Boudabous, A.; Borin, S.; Manino, A.; Bandi, C.; et al. Gut microbiome dysbiosis and honeybee health. J. Appl. Entomol. 2011, 135, 524-533. [CrossRef]

5. Maes, P.W.; Rodrigues, P.A.; Oliver, R.; Mott, B.M.; Anderson, K.E. Diet-related gut bacterial dysbiosis correlates with impaired development, increased mortality and Nosema disease in the honeybee (Apis mellifera). Mol. Ecol. 2016, 25, 5439-5450. [CrossRef] [PubMed]

6. Schwarz, R.S.; Moran, N.A.; Evans, J.D. Early gut colonizers shape parasite susceptibility and microbiota composition in honey bee workers. Proc. Natl. Acad. Sci. USA 2016, 113, 9345-9350. [CrossRef]

7. Raymann, K.; Shaffer, Z.; Moran, N.A. Antibiotic exposure perturbs the gut microbiota and elevates mortality in honeybees. PLoS Biol. 2017, 15, e2001861. [CrossRef]

8. Aronstein, K.A.; Murray, K.D. Chalkbrood disease in honey bees. J. Invertebr. Pathol. 2010, 103, $20-29$. [CrossRef]

9. Evison, S.E. Chalkbrood: Epidemiological perspectives from the host-parasite relationship. Curr. Opin. Insect Sci. 2015, 10, 65-70. [CrossRef]

10. Garrido-Bailón, E.; Higes, M.; Martínez-Salvador, A.; Antúnez, K.; Botías, C.; Meana, A.; Prieto, L.; Martín-Hernández, R. The prevalence of the honeybee brood pathogens Ascosphaera apis, Paenibacillus larvae and Melissococcus plutonius in Spanish apiaries determined with a new multiplex PCR assay. Microb. Biotechnol. 2013, 6, 31-39. [CrossRef]

11. Zaghloul, O.A.; Mourad, A.K.; El Kady, M.B.; Nemat, F.M.; Morsy, M.E. Assessment of losses in honey yield due to the chalck-brood disease with reference to the determination of its economic injury levels in Egypt. Commun. Agric. Appl. Biol. Sci. 2005, 70, 703-714. [PubMed]

12. Reynaldi, F.J.; Lucia, M.; Garcia, M.L.G. Ascosphaera apis, the entomopathogenic fungus affecting larvae of native bees (Xylocopa augusti): First report in South America. Rev. Iberoam. Micol. 2015, 32, 261-264. [CrossRef] [PubMed]

13. Vojvodic, S.; Boomsma, J.J.; Eilenberg, J.; Jensen, A.B. Virulence of mixed fungal infections in honey bee brood. Front. Zool. 2012, 9, 5. [CrossRef]

14. Fowler, A.E.; Irwin, R.E.; Adler, L.S. Parasite defense mechanisms in bees: Behavior, immunity, antimicrobials, and symbionts. Emerg. Top. Life Sci. 2019, ETLS20190069. [CrossRef]

15. Alberoni, D.; Baffoni, L.; Gaggiìa, F.; Ryan, P.M.; Murphy, K.; Ross, P.R.; Santon, C.; Di Gioia, D. Impact of beneficial bacteria supplementation on the gut microbiota, colony development and productivity of Apis mellifera L. Benef. Microbes 2018, 9, 269-278. [CrossRef] [PubMed]

16. Ptaszyńska, A.A.; Borsuk, G.; Zdybicka-Barabas, A.; Cytryńska, M.; Małek, W. Are commercial probiotics and prebiotics effective in the treatment and prevention of honeybee nosemosis C? Parasitol. Res. 2016, 115, 397-406. [CrossRef] [PubMed]

17. Pătruică, S.; Mot, D. The effect of using prebiotic and probiotic products on intestinal micro-flora of the honeybee (Apis mellifera carpatica). Bull. Entomol. Res. 2012, 102, 619-623. [CrossRef]

18. Audisio, M.C. Gram-positive bacteria with probiotic potential for the Apis mellifera L. honey bee: The experience in the Northwest of Argentina. Probiot. Antimicrob. Proteins 2017, 9, 22-31. [CrossRef]

19. Audisio, M.C.; Benítez-Ahrendts, M.R. Lactobacillus johnsonii CRL1647, isolated from Apis mellifera L. bee-gut, exhibited a beneficial effect on honeybee colonies. Benef. Microbes 2011, 2, 29-34. [CrossRef] 
20. Baffoni, L.; Gaggiìa, F.; Alberoni, D.; Cabbri, R.; Nanetti, A.; Biavati, B.; Di Gioia, D. Effect of dietary supplementation of Bifidobacterium and Lactobacillus strains in Apis mellifera L. against Nosema ceranae. Benef. Microbes 2016, 7, 45-51. [CrossRef]

21. Vásquez, A.; Forsgren, E.; Fries, I.; Paxton, R.J.; Flaberg, E.; Szekely, L.; Olofsson, T.C. Symbionts as major modulators of insect health: Lactic acid bacteria and honeybees. PLoS ONE 2012, 7, e33188. [CrossRef]

22. Endo, A.; Irisawa, T.; Futagawa-Endo, Y.; Takano, K.; du Toit, M.; Okada, S.; Dicks, L.M. Characterization and emended description of Lactobacillus kunkeei as a fructophilic lactic acid bacterium. Int. J. Syst. Evol. Microbiol. 2012, 62, 500-504. [CrossRef] [PubMed]

23. Endo, A.; Salminen, S. Honeybees and beehives are rich sources for fructophilic lactic acid bacteria. Syst. Appl. Microbiol. 2013, 36, 444-448. [CrossRef] [PubMed]

24. Filannino, P.; Di Cagno, R.; Tlais, A.Z.A.; Cantatore, V.; Gobbetti, M. Fructose-rich niches traced the evolution of lactic acid bacteria toward fructophilic species. Crit. Rev. Microbiol. 2019, 45, 65-81. [CrossRef] [PubMed]

25. Olofsson, T.C.; Butler, È.; Markowicz, P.; Lindholm, C.; Larsson, L.; Vásquez, A. Lactic acid bacterial symbionts in honeybees-an unknown key to honey's antimicrobial and therapeutic activities. Int. Wound J. 2016, 13, 668-679. [CrossRef]

26. Berríos, P.; Fuentes, J.A.; Salas, D.; Carreno, A.; Aldea, P.; Fernandez, F.; Trombert, A.N. Inhibitory effect of biofilm-forming Lactobacillus kunkeei strains against virulent Pseudomonas aeruginosa in vitro and in honeycomb moth (Galleria mellonella) infection model. Benef. Microbes 2018, 9, 257-268. [CrossRef]

27. Butler, E.; Alsterfjord, M.; Olofsson, T.; Karlsson, C.; Malmström, J.; Vásquez, A. Proteins of novel lactic acid bacteria from Apis mellifera mellifera: An insight into the production of known extra-cellular proteins during microbial stress. BMC Microbiol. 2013, 13, 235. [CrossRef]

28. Arredondo, D.; Castelli, L.; Porrini, M.P.; Garrido, P.M.; Eguaras, M.J.; Zunino, P.; Antúnez, K. Lactobacillus kunkeei strains decreased the infection by honey bee pathogens Paenibacillus larvae and Nosema ceranae. Benef. Microbes 2018, 9, 279-290. [CrossRef]

29. Bartel, L.C.; Abrahamovich, E.; Mori, C.; Lopez, A.C.; Alippi, A.M. Bacillus and Brevibacillus strains as potential antagonists of Paenibacillus larvae and Ascosphaera apis. J. Apic. Res. 2019, 58, 117-132. [CrossRef]

30. Al-Ghamdi, A.; Khan, K.; Ansari, M.; Almasaudi, S.; AL-Kahtani, S. Effect of gut bacterial isolates from Apis mellifera jemenitica on Paenibacillus larvae infected bee larvae. Saudi J. Biol. Sci. 2017, 25, 383-387. [CrossRef]

31. Forsgren, E.; Olofsson, T.C.; Váasquez, A.; Fries, I. Novel lactic acid bacteria inhibiting Paenibacillus larvae in honey bee larvae. Apidologie 2010, 41, 99-108. [CrossRef]

32. Janashia, I.; Choiset, Y.; Rabesona, H.; Hwanhlem, N.; Bakuradze, N.; Chanishvili, N.; Haertlé, T. Protection of honeybee Apis mellifera by its endogenous and exogenous lactic flora against bacterial infections. Ann. Agrar. Sci. 2016, 14, 177-181. [CrossRef]

33. Omar, M.O.M.; Moustafa, A.M.; Ansari, M.J.; Anwar, A.M.; Fahmy, B.F.; Al-Ghamdi, A.; Nuru, A. Antagonistic effect of gut bacteria in the hybrid Carniolan honey bee, Apis Mellifera Carnica, against Ascosphaera apis, the causal organism of chalkbrood disease. J. Apic. Sci. 2014, 58, 17-27. [CrossRef]

34. Sabaté, D.C.; Carrillo, L.; Audisio, M.C. Inhibition of Paenibacillus larvae and Ascosphaera apis by Bacillus subtilis isolated from honeybee gut and honey samples. Res. Microbiol. 2009, 160, 193-199. [CrossRef]

35. Tejerina, M.R.; Cabana, M.J.; Carrillo, L.; Benitez-Ahrendts, M.R. Effect of Lactic Bacteria on Ascosphaera apis and A. atra. Asian J. Agric. Food. Sci. 2018, 6, 123-128. [CrossRef]

36. Kostecka, M.; Niewiadomy, A. Antifungal activity of new series of compound against Ascosphaera apis. Mikol. Lek. 2010, 17, 169-171.

37. Chorbinski, P. Susceptibility of Ascosphaera apis strains to antifungal preparations. Med. Weter. 2003, 59, 1137-1139.

38. Sarwar, M. Fungal diseases of honey bees (Hymenoptera: Apidae) that induce considerable losses to colonies and protocol for treatment. Int. J. Zool. Stud. 2016, 1, 8-13.

39. Frazier, M.; Mullin, C.; Frazier, J.; Ashcraft, S. What have pesticides got to do with it? Am. Bee J. 2008, 148, 521-524.

40. Ansari, M.J.; Al-Ghamdi, A.; Usmani, S.; Khan, K.A.; Alqarni, A.S.; Kaur, M.; Al-Waili, N. In vitro evaluation of the effects of some plant essential oils on Ascosphaera apis, the causative agent of Chalkbrood disease. Saudi J. Biol. Sci. 2017, 24, 1001-1006. [CrossRef]

41. Chantawannakul, P.; Puchanichanthranon, T.; Wongsiri, S. Inhibitory effects of some medicinal plant extracts on the growth of Ascosphaera apis. ACTA Hortic. 2005, 678, 183-189. [CrossRef] 
42. Chaimanee, V.; Thongtue, U.; Sornmai, N.; Songsri, S.; Pettis, J.S. Antimicrobial activity of plant extracts against the honeybee pathogens, Paenibacillus larvae and Ascosphaera apis and their topical toxicity to Apis mellifera adults. J. Appl. Microbiol. 2017, 123, 1160-1167. [CrossRef] [PubMed]

43. Boudegga, H.; Boughalleb, N.; Barbouche, N.; Ben Hamouda, M.H.; Mahjoub, M.E. In vitro inhibitory actions of some essential oils on Ascosphaera apis, a fungus responsible for honey bee chalkbrood. J. Apic. Res. 2010, 49, 236-242. [CrossRef]

44. Dellacasa, A.D.; Bailac, P.N.; Ponzi, M.I.; Ruffinengo, S.R.; Eguaras, M.J. In vitro activity of essential oils from San Luis-Argentina against Ascosphaera apis. J. Essent. Oil Res. 2003, 15, 282-285. [CrossRef]

45. Dunn, L.L.; Davidson, P.M.; Critzer, F.J. Antimicrobial efficacy of an array of essential oils against lactic acid bacteria. J. Food Sci. 2016, 81, M438-M444. [CrossRef] [PubMed]

46. Testa, B.; Lombardi, S.J.; Macciola, E.; Succi, M.; Tremonte, P.; Iorizzo, M. Efficacy of olive leaf extract (Olea europaea L. cv Gentile di Larino) in marinated anchovies (Engraulis encrasicolus, L.) process. Heliyon 2019, 5, e01727. [CrossRef]

47. García-Ruiz, A.; Bartolomé, B.; Martínez-Rodríguez, A.J.; Pueyo, E.; Martín-Álvarez, P.J.; Moreno-Arribas, M.V. Potential of phenolic compounds for controlling lactic acid bacteria growth in wine. Food Control 2008, 19, 835-841. [CrossRef]

48. Rivas-Sendra, A.; Landete, J.M.; Alcántara, C.; Zúñiga, M. Response of Lactobacillus casei BL23 to phenolic compounds. J. Appl. Microbiol. 2011, 111, 1473-1481. [CrossRef]

49. Lombardi, S.J.; Tremonte, P.; Succi, M.; Testa, B.; Pannella, G.; Tipaldi, L.; Sorrentino, E.; Coppola, R.; Iorizzo, M. Effect of phenolic compounds on the growth and L-malic acid metabolism of Oenococcus oeni. J. Life Sci. 2012, 6, 1225. [CrossRef]

50. Raymann, K.; Moran, N.A. The role of the gut microbiome in health and disease of adult honey bee workers. Curr. Opin. Insect. Sci. 2018, 26, 97-104. [CrossRef]

51. Wu, M.; Sugimura, Y.; Taylor, D.; Yoshiyama, M. Honeybee gastrointestinal bacteria for novel and sustainable disease control strategies. J. Dev. Sustain. Agric. 2013, 8, 85-90. [CrossRef]

52. Crowley, S.; Mahony, J.; van Sinderen, D. Current perspectives on antifungal lactic acid bacteria as natural bio-preservatives. Trends Food Sci. Technol. 2013, 33, 93-109. [CrossRef]

53. Le Lay, C.; Coton, E.; Le Blay, G.; Chobert, J.M.; Haertlé, T.; Choiset, Y.; Van Long, N.N.; Meslet-Cladière, L.; Mounier, J. Identification and quantification of antifungal compounds produced by lactic acid bacteria and propionibacteria. Int. J. Food Microbiol. 2016, 239, 79-85. [CrossRef] [PubMed]

54. Ngang, J.J.E.; Yadang, G.; Kamdem, S.L.S.; Kouebou, C.P.; Fanche, S.A.Y.; Kougan, D.L.T.; Tsoungui, A.; Etoa, F.X. Antifungal properties of selected lactic acid bacteria and application in the biological control of ochratoxin A producing fungi during cocoa fermentation. Biocontrol Sci. Technol. 2015, 25, 245-259. [CrossRef]

55. Sorrentino, E.; Tremonte, P.; Succi, M.; Iorizzo, M.; Pannella, G.; Lombardi, S.J.; Sturchio, M.; Coppola, R. Detection of Antilisterial Activity of 3-Phenyllactic Acid Using Listeria innocua as a Model. Front. Microbiol. 2018, 9, 1373. [CrossRef] [PubMed]

56. Kleerebezem, M.; Hols, P.; Bernard, E.; Rolain, T.; Zhou, M.; Siezen, R.J.; Bron, P.A. The extracellular biology of the lactobacilli. FEMS Microbiol. Rev. 2010, 34, 199-230. [CrossRef]

57. Kinoshita, H.; Uchida, H.; Kawai, Y.; Kawasaki, T.; Wakahara, N.; Matsuo, H.; Watanabe, M.; Kitazawa, H.; Ohnuma, S.; Miura, K.; et al. Cell surface Lactobacillus plantarum LA 318 glyceraldehyde-3-phosphate dehydrogenase (GAPDH) adheres to human colonic mucin. J. Appl. Microbiol. 2008, 104, 1667-1674. [CrossRef]

58. Åvall-Jääskeläinen, S.; Palva, A. Lactobacillus surface layers and their applications. FEMS Microbiol. Rev. 2005, 29, 511-529. [CrossRef]

59. Janashia, I.; Choiset, Y.; Jozefiak, D.; Déniel, F.; Coton, E.; Akbar, A.; Moosavi-Movahedi, A.A.; Chanishvili, N.; Haertlé, T. Beneficial protective role of endogenous lactic acid bacteria against mycotic contamination of honeybee beebread. Probiot. Antimicrob. Proteins 2018, 10, 638-646. [CrossRef]

60. Daisley, B.A.; Pitek, A.P.; Chmiel, J.A.; Al, F.K.; Chernyshova, A.M.; Faragalla, K.M.; Burton, J.P.; Thompson, G.J.; Reid, G. Novel probiotic approach to counter Paenibacillus larvae infection in honey bees. ISME J. 2020, 14, 476-491. [CrossRef] 
61. Santarmaki, V.; Kourkoutas, Y.; Zoumpopoulou, G.; Mavrogonatou, E.; Kiourtzidis, M.; Chorianopoulos, N.; Tassou, C.; Tsakalidou, E.; Simopoulos, C.; Ypsilantis, P. Survival, intestinal mucosa adhesion, and immunomodulatory potential of Lactobacillus plantarum strains. Curr. Microbiol. 2017, 74, 1061-1067. [CrossRef] [PubMed]

62. Trunk, T.; Khalil, H.S.; Leo, J.C. Bacterial autoaggregation. AIMS Microbiol. 2018, 4, 140-164. [CrossRef] [PubMed]

63. Del Re, B.; Sgorbati, B.; Miglioli, M.; Palenzona, D. Adhesion, autoaggregation and hydrophobicity of 13 strains of Bifidobacterium longum. Lett. Appl. Microbiol. 2000, 31, 438-442. [CrossRef]

64. Pessoa, W.F.B.; Melgaço, A.C.C.; de Almeida, M.E.; Ramos, L.P.; Rezende, R.P.; Romano, C.C. In vitro activity of Lactobacilli with probiotic potential isolated from Cocoa fermentation against Gardnerella vaginalis. BioMed Res. Int. 2017, 2017, 3264194. [CrossRef] [PubMed]

65. Bouchard, D.S.; Bianca Seridan, B.; Saraoui, T.; Rault, L.; Germon, P.; Gonzalez-Moreno, C.; Nader-Macias, F.M.E.; Baud, D.; François, P.; Chuat, V.; et al. Lactic acid bacteria isolated from bovine mammary microbiota: Potential allies against bovine mastitis. PLoS ONE 2015, 29, e144831. [CrossRef]

66. Gandomi, H.; Farhangfar, A.; Misaghi, A.; Noori, N. Auto and co-aggregation, hydrophobicity and adhesion properties of Lactobacillus plantarum strains isolated from Siahmazgi traditional cheese. Food Health J. 2019, 2 , $1-5$.

67. Collado, M.C.; Meriluoto, J.; Salminen, S. Adhesion and aggregation properties of probiotic and pathogen strains. Eur. Food Res. Technol. 2008, 226, 1065-1073. [CrossRef]

68. Ekmekci, H.; Aslim, B.; Ozturk, S. Characterization of vaginal lactobacilli coaggregation ability with Escherichia coli. Microbiol. Immunol. 2009, 53, 59-65. [CrossRef]

69. Marin, M.L.; Benito, Y.; Pin, C.; Fernandez, M.F.; Garcia, M.L.; Selgas, M.D.; Casas, C. Lactic acid bacteria: Hydrophobicity and strength of attachment to meat surfaces. Lett. Appl. Microbiol. 1997, 24, 14-18. [CrossRef]

70. O’Toole, G.; Kaplan, H.B.; Kolter, R. Biofilm formation as microbial development. Annu. Rev. Microbiol. 2000, 54, 49-79. [CrossRef]

71. Sakandar, H.A.; Kubow, S.; Sadiq, F.A. Isolation and in-vitro probiotic characterization of fructophilic lactic acid bacteria from Chinese fruits and flowers. LWT Food Sci. Technol. 2019, 104, 70-75. [CrossRef]

72. Audisio, M.C.; Torres, M.J.; Sabaté, D.C.; Ibarguren, C.; Apella, M.C. Properties of different lactic acid bacteria isolated from Apis mellifera L. bee-gut. Microbiol. Res. 2011, 166, 1-13. [CrossRef] [PubMed]

73. Van de Guchte, M.; Serror, P.; Chervaux, C.; Smokvina, T.; Ehrlich, S.D.; Maguin, E. Stress responses in lactic acid bacteria. Anton Leeuwenhoek 2002, 82, 187-216. [CrossRef]

74. Papadimitriou, K.; Alegría, Á.; Bron, P.A.; de Angelis, M.; Gobbetti, M.; Kleerebezem, M.; Lemos, J.A.; Linares, D.M.; Ross, P.; Stanton, C.; et al. Stress physiology of lactic acid bacteria. Microbiol. Mol. Biol. Rev. 2016, 80, 837-890. [CrossRef]

75. Vasileva, T.; Bivolarski, V.; Michailova, G.; Salim, A.; Rabadjiev, Y.; Ivanova, I.; Iliev, I. Glucansucrases produced by fructophilic lactic acid bacteria Lactobacillus kunkeei $\mathrm{H} 3$ and $\mathrm{H} 25$ isolated from honeybees. J. Basic Microbiol. 2017, 57, 68-77. [CrossRef]

76. Meng, X.; Gangoiti, J.; Wang, X.; Grijpstra, P.; Van Leeuwen, S.S.; Pijning, T.; Dijkhuizen, L. Biochemical characterization of a GH70 protein from Lactobacillus kunkeei DSM 12361 with two catalytic domains involving branching sucrase activity. Appl. Microbiol. Biotechnol. 2018, 102, 7935-7950. [CrossRef]

77. Davey, M.E.; O'toole, G.A. Microbial biofilms: From ecology to molecular genetics. Microbiol. Mol. Biol. Rev. 2000, 64, 847-867. [CrossRef]

78. Djukic, M.; Poehlein, A.; Strauß, J.; Tann, F.J.; Leimbach, A.; Hoppert, M.; Daniel, R. High quality draft genome of Lactobacillus kunkeei EFB6, isolated from a German European foulbrood outbreak of honeybees. Stand. Genom. Sci. 2015, 10, 16. [CrossRef]

79. Tamarit, D.; Ellegaard, K.M.; Wikander, J.; Olofsson, T.; Vasquez, A.; Andersson, S.G. Functionally structured genomes in Lactobacillus kunkeei colonizing the honey crop and food products of honeybees and stingless bees. Genome Biol. Evol. 2015, 7, 1455-1473. [CrossRef]

80. Billiet, A.; Meeus, I.; Cnockaert, M.; Vandamme, P.; Van Oystaeyen, A.; Wäckers, F.; Smagghe, G. Effect of oral administration of lactic acid bacteria on colony performance and gut microbiota in indoor-reared bumblebees (Bombus terrestris). Apidologie 2017, 48, 41-50. [CrossRef]

81. Alberoni, D.; Gaggìa, F.; Baffoni, L.; Di Gioia, D. Beneficial microorganisms for honey bees: Problems and progresses. Appl. Microbiol. Biotechnol. 2016, 100, 9469-9482. [CrossRef] [PubMed] 
82. Crotti, E.; Balloi, A.; Hamdi, C.; Sansonno, L.; Marzorati, M.; Gonella, E.; Favia, G.; Cherif, A.; Bandi, C.; Alma, A.; et al. Microbial symbionts: A resource for the management of insect-related problems. Microb. Biotechnol. 2011, 5, 307-317. [CrossRef] [PubMed]

83. Maruščáková, I.C.; Schusterová, P.; Bielik, B.; Toporčák, J.; Bíliková, K.; Mudroňová, D. Effect of application of probiotic pollen suspension on immune response and gut microbiota of honey bees (Apis mellifera). Probiot. Antimicrob. Proteins 2020, 1-8. [CrossRef] [PubMed]

84. Kwong, W.K.; Mancenido, A.L.; Moran, N.A. Immune system stimulation by the native gut microbiota of honey bees. R. Soc. Open Sci. 2017, 4, 170003. [CrossRef]

85. Di Donato, A.P. Characterization of Lactic Acid Bacteria Isolated from Apis mellifera L. and Hive Products. Master's Thesis, University of Molise, Campobasso, Italy, 15 February 2016.

86. Magnusson, J.; Ström, K.; Roos, S.; Sjögren, J.; Schnürer, J. Broad and complex antifungal activity among environmental isolates of lactic acid bacteria. FEMS Microbiol. Lett. 2003, 219, 129-135. [CrossRef]

87. Cozzolino, A.; Vergalito, F.; Tremonte, P.; Iorizzo, M.; Lombardi, S.J.; Sorrentino, E.; Luongo, D.; Coppola, R.; Di Marco, R.; Succi, M. Preliminary evaluation of the safety and probiotic potential of Akkermansia muciniphila DSM 22959 in Comparison with Lactobacillus rhamnosus GG. Microorganisms 2020, 8, 189. [CrossRef] [PubMed]

(C) 2020 by the authors. Licensee MDPI, Basel, Switzerland. This article is an open access article distributed under the terms and conditions of the Creative Commons Attribution (CC BY) license (http://creativecommons.org/licenses/by/4.0/). 